\title{
CHALLENGES AND OPPORTUNITIES \\ FOR PROPERTY ACADEMICS
}

\author{
GRAEME NEWELL \\ University of Western Sydney
}

\section{ABSTRACT}

This paper is the keynote address presented by Professor Graeme Newell at the $13^{\text {th }}$ PRRES Conference in Fremantle over 21-24 January 2007 on the challenges and opportunities for property academics. This keynote address was sponsored by the RICS.

Keywords: University landscape, property research, professional accreditation, RQF, academic opportunities

\section{INTRODUCTION}

The university sector landscape has changed considerably in recent years. Declining university budgets, re-positioning of property departments and significantly higher salaries for better property graduates in the capital markets have all placed pressure on the development of the next generation of property academics. Similarly, the introduction of the Research Quality Framework (RQF) in Australia will see an increased focus on research within the university sector and have a significant impact on future property academic appointments.

Despite these pressures, this also presents opportunities for both established and new property academics to review their profiles to significantly enhance their property academic career opportunities. This paper will review the current university landscape for property academics and assess the strategies available for property academics to further develop their academic career prospects; in particular, career strategies for new property research agendas, enhanced international recognition, industry linkages and strong academic leadership will be discussed.

\section{THE ACADEMIC LANDSCAPE: POSITIVES}

Property education has now been in the Australian university sector for over thirty years. This has seen a number of positive factors impact on the university landscape for property academics, including:

- development of regional real estate societies (eg: PRRES, ERES, ARES, AsRES) throughout the world, providing a structure and focus to our property education and research activities 
- significant increase in the number of journals available for property research, with currently over 35 refereed property journals available as well as related journals which publish property research

- increased access to property information, as well as an increased willingness by the property industry to share property information. Organisations such as IPD, JLL, UBS and PIR have been leaders in this area, with databases such as Datastream giving access to historic information for various property, economic and financial information

- establishment of new property organisations in the last five years which want property academics linked into their activities and strongly support academic research; eg: European Public Real Estate Association (EPRA), Asian Public Real Estate Association (APREA), Investors in Non-listed Real Estate Vehicles (INREV), Asian Real Estate Association (AREA) and Investment Property Forum (IPF); these are in addition to the already long-term established players such as NCREIF, NAREIT, API and the RICS

- establishment of new property vehicles linked into the capital markets, including LPTs, REITs, CMBS, futures, derivatives, as well as property now truly being an international asset class

- diverse range of new property careers for our graduates, moving beyond the traditional property careers of valuation, property management and property development to now include property funds management, investment banking and asset consulting, with many of our top property students seeing funds management and investment banking as their longer-term career goals and seeing only approximately $15 \%$ of property graduates in Australia going into valuation

- recent promotion of property academics to professor, associate professor and senior lecturer, with PRRES being a key factor in their promotion success

- improved communication, seeing collaborative reports developed via email as well as downloading property industry reports and data from property industry websites

- $\quad$ improving quality of property students; often they are very focused with specific career goals; also significant increase in number of women doing property degrees in Australia

- $\quad$ strong support from property industry leaders; often these leaders are our own property graduates now wanting to give something back to support property education.

\section{THE ACADEMIC LANDSCAPE: NEGATIVES}

But there has also been a downside that has impacted on being a property academic in recent years, including:

- declining university budgets, with an increased reliance on non-government income sources 
- increasing student numbers, with property seen as an increasingly attractive area, given the strong property market growth over the last ten years. This has resulted in many first year intakes into property programs being over 150 students, without additional property staff

- introduction of a generic first year in many universities, driven more by financial reasons than by educational reasons. This has presented difficulties in establishing a strong property context early in the degree programs; typically less than $25 \%$ of year one subjects are property-related

- re-positioning of property departments, as universities seek to establish larger Schools, with resulting loss of identity or "badging" for property in School title etc

- ageing academic staff cohort; a significant number of property academics will retire in the next 5-10 years; often these staff have industry-based backgrounds and are quality teaching focused; in many cases, they have played a leading role in shaping property education in the region and have run the property degrees since they were first established in the university sector in the Pacific Rim

- many staff have had to leave their universities to get promoted; whilst this has brought new blood into property departments, it has seen a significant loss of academic knowledge and experience, and often the staff have not been replaced

- a number of professorial positions are currently not filled, despite readvertising

- significantly enhanced research focus in promotion applications, requiring refereed publications, external research grants and impact factor analysis; however, only a small number of property journals are in the SSCI

- university expectations of all new staff having an increased focus on research

- introduction of RQF in Australia, seeing an increased focus on research and a potential separation of staff regarding teaching versus research focus

- increasing influence of the finance discipline in shaping property research, with an increased focus on methodology and finance references, and less emphasis on property industry relevance; particularly for property academics seeking to publish in the US real estate journals.

\section{THE MAJOR CHALLENGES}

Overall, this now sees significantly higher salaries for property graduates in the property industry, clearly reflecting the impact of the capital markets, the global growth in property funds management and a strong commercial property market over the last ten years. As such, the time and cost of doing a $\mathrm{PhD}$ to start as a property lecturer is seen as being unattractive to our property graduates.

This sees the major challenge for universities around the world as being how to develop the next generation of property academics; this challenge also applies to various other professional disciplines such as accounting. 
This challenge has three dimensions:

- next generation of property academics?

- impact of RQF on property education in Australia

- ongoing accreditation issues with RICS and API.

These issues will be discussed separately in subsequent sections of this paper.

\section{NEXT GENERATION OF PROPERTY ACADEMICS?}

The significant change amongst property academics will be a movement away from academics with a strong professional background to those with a strong academic background and a subsequent focus on property research. The resulting future profile of property academics over the next 5-10 years will see new property academics with $\mathrm{PhDs}$, with limited (or no) property industry experience and being international, reflecting career mobility, academic salary differences between countries and lifestyle issues. In many cases, they will not have property backgrounds, but will come from related areas (eg: finance, economics) and re-engineer their focus to property; this is already happening in several universities. International recruitment searches are now the norm to attract the best staff from this international pool.

Support from the property industry and property foundations will be important to overcome this mismatch between academic salaries and professional salaries. This will include:

- $\quad$ PhD scholarship top-ups

- additional resources to property centres; eg: computers, data. Groups such as IPF in the UK are already doing this

- fractional academic appointments, funded by external property foundations

- salary supplementation for property academics

- naming rights; eg: Mirvac's role at Bond University is an excellent example

- more flexible view by universities regarding staff doing consulting and subsequent financial sharing arrangements.

Importantly, many of our property graduates are now in senior positions in the property industry and are keen to give something back, both in financial and non-financial terms.

Other strategies with our current $\mathrm{PhD}$ students are to clearly reinforce the enhanced research perspective beyond their $\mathrm{PhD}$. This includes:

- $\quad$ publishing during their $\mathrm{PhD}$

- $\quad$ encouraging them to present their research at conferences 
- doing joint publications outside their $\mathrm{PhD}$, via research assistance and joint authorship with colleagues

- $\quad$ personal discussions with supervisors regarding life after the $\mathrm{PhD}$ and what is needed to be a property academic.

This different profile of future property academics will see some changes in property degrees; particularly concerning the delivery of the professional component in the property degrees where new staff have limited experience and an increased focus on research to advance their academic careers. This changing nature of property degrees will involve:

- accreditation issues for RICS and API, particularly concerning the mismatch between university expectations and industry expectations; discussed more fully in subsequent section of this paper

- increased use of guest lecturers as specialist professionals, as well as adjunct professor appointments for high level professionals

- increased expectations of industry having to give something back to support property education

- review of the traditional presentation model of "two lectures and one tutorial" to educational models that are more efficient; particularly for large groups. This will involve workshops, focus on student learning instead of staff delivery, use of delivery options including structured tasks using the internet, and reduced number of small components of assessment. Terry Boyd at QUT has been one of the leaders in this area; particularly concerning the redesigning and repackaging of property programs to accommodate the specific learning needs of postgraduate property students.

\section{IMPACT OF RQF ON PROPERTY EDUCATION}

The RQF procedures to assess university research are similar to that seen with the RAE in the UK. This will see the current focus on quantity shift to a focus of research quality (eg: journal quality) and research impact (eg: government policy, industry). The immediate impact will be the lesser status given to refereed conference papers, with the potential flow-on effect to putting future conference funding support at risk unless you have a high conversion rate from conference paper to refereed journal publication.

Increasingly, universities will want "RQF-ready" staff who have a track record of publications and external research grants. Whilst this may give mobility and enhanced promotion prospects to research active staff, other current staff with lesser research backgrounds will see it more as a threat than an opportunity.

Should you focus on research? Your university will definitely say yes; but universities will be very selective who they include in the RQF process. Universities will not want to 
see poor RQF ratings in discipline areas (and low research dollars generated) in certain categories. Where property positions remains to be seen and universities will sort this out in 2007; in some cases, property may not ever be included in their RQF portfolio submission. Property is also not likely to be directly represented on the various RQF assessment panels. Importantly, this RQF process for implementation in 2008 will lock in research funding for the next six years. Similarly, at a personal level, most academics recognise that research is essential to get promoted in universities today, with this focus expected to increase as universities position for the current RQF and the subsequent RQF in 2012. Already, some universities have been very aggressive in this area.

The RQF will also impact on the nature of property research that is done in the future. Theoretical research will take on more importance, as opposed to applied research which is the current strength of most PRRES members. Reliance on the SSCI as the citations benchmark presents difficulties, with only three property journals included; namely Real Estate Economics, Journal of Real Estate Finance and Economics, Journal of Real Estate Research; additionally some land economics journals are also included in the SSCI. This will present major challenges for property academics as they seek to upgrade the calibre of the journals they publish in; as well as seeking external research funding (eg: ARC). Again, for academics with a professional background, this will present a major challenge.

\section{ACCREDITATION ISSUES}

The changing nature of property education will also present accreditation issues for the RICS and API; particularly concerning the course accreditation criteria. Accreditation has changed considerably over the last twenty years, moving away from a very prescriptive checklist to a strategic alliance based around the key areas of student entry, student satisfaction, staff research and employment of graduates.

However, the focus by universities on research and the focus by industry on professional experience will see a mismatch in expectations, with some concessions needed in the future to rationalise this mismatch. A recent RICS report on "The future of surveying education" (RICS, 2006) highlighted many of these issues; in particular:

- is the definition of research too narrow; should it be expanded to include discovery and application, including market-based research and case-studies

- need to expand the focus on teaching excellence, with a trade-off possible for some staff without a research focus to offset this with evidence of teaching excellence to reflect diversity in the academic staff profiles.

This further highlights the issue of education versus training and the respective roles of the universities and professional associations in these areas; in particular, the role of professional experience. This will form the focus for the ongoing debate regarding this 
future mismatch between university expectations and industry expectations of the property graduates' skills set.

\section{OPPORTUNITIES}

Change always brings opportunities for both current and new property academics, giving opportunities for academics to review their profile and enhance their career. Key areas are research agendas, international recognition, industry linkages and academic leadership.

\section{Expand your research agenda}

The key catalysts to expanding your research agenda are the RQF, an increased range of journals and improved access to property information. Many of the traditional research areas are being replaced with new research areas, often via multi-disciplinary research clusters which have a critical mass of researchers. Often these research groups are in a different Faculty. Academics need to re-assess whether they want to be involved in these new groups (that often come with internal university-priority research funding) or continue with their traditional research groupings.

Importantly, new property research agendas have emerged in recent years; particularly in the areas of sustainability, emerging property market dynamics (eg: Asia, Eastern Europe), investment strategy and decision-making, and emerging property sectors (eg: self-storage, retirement, health care, infrastructure). Much of this has an industry focus which is the strength of most PRRES researchers, and only requires a slight re-alignment of your research priorities to focus your skills on these new areas. Many of the "remembered" papers are not heavy number-crunching econometric exercises, but are papers that give market insight via simple, yet incisive papers. Classic examples of this recently are Ling (2006), Gallimore and McAllister (2004), Chin et al (2006) and Lim et al (2006); all are definitely worth re-reading.

The Pacific Rim Property Research Journal (PRPRJ) has had a significant role in expanding PRRES members' research agendas by supporting new researchers. For example, $20 \%$ of papers in PRPRJ in 2006 were by new authors, with 18 universities represented amongst these 2006 authors, as well as two papers published by $\mathrm{PhD}$ students. However, for most PRRES researchers, their conference paper conversion rate is low; simply because they do not submit their revised conference paper to a journal. PRPRJ always needs good papers, with the RQF likely to see funded conference attendance put at risk unless you can convert your conference paper to a refereed journal article. This will take on increased importance in the RQF as journal impact analysis is a key component, both in terms of citations, impact factors and your submitted portfolio of best papers to demonstrate the quality of your property research.

Increased focus will also need to be given to external research funding opportunities. Research funding providers such as ARC Linkage Grants, AHURI and CRCs will receive 
a higher profile. Others with a stronger industry focus include the RICS Education Trust and API Education Trust. Recent years have seen the IPF in the UK raise $£ 1$ million for research projects funded by leading property industry players; an outstanding achievement. Hopefully, Australia can produce something equivalent in the future, with the Australian Property Research Forum setting up a similar research linkage between property academics and the property industry.

\section{Enhance your international recognition}

As well as PRRES, ARES, ERES and AsRES have outstanding annual conferences with over 400 property researchers attending in many instances; they are outstanding conferences in superb venues. Importantly, they provide the major opportunity for networking; this is essential today for an effective research agenda and keeping up-todate. It also gives you access to the major international journals, which are giving an increasing profile to international property research.

Overall, my three best property research decisions in my career have been:

1. get involved in PRRES

2. go international via involvement in ARES and ERES over the last 15 years

3. re-focus this research agenda into Asia via research, friendships and linkages in recent years.

\section{Enhance your industry linkages}

We pride ourselves in preparing graduates for the property industry. But it is an area that we can develop a lot more effectively; particularly as in the future, it will become an increased priority regarding providing professional experience in an property degree, as well as a source of property funding and information. This will be facilitated by many of our property graduates now being in senior roles in the property industry.

Opportunities exist in the following areas:

- scholarships

- prizes

- research funding

- information/data

- interviews with senior players for student projects and research projects

- guest lecturers

- job opportunities for students;

in most instances, I have found people across the property industry are happy to assist at various levels to add value in our property programs. 


\section{Enhance your academic leadership}

We constantly need to be reviewing our property programs to ensure they are up-to-date. Two key expanding areas that all property graduates need knowledge in are the areas of corporate real estate and international property. New subjects in these areas typically meet with high student demand and student interest.

Other areas worth developing are:

- executive programs, by targeting specific companies with tailored programs

- property-related Masters students; this is a growth market, with students often having degrees in finance, economics or building and now working in the property area requiring specific property knowledge to further advance their careers

- workplace-aligned Masters by research, with a research task at work identified and structured into a formal part-time research masters degree.

\section{CONCLUSION}

This keynote address has focused on the challenges and opportunities for property academics; particularly focusing on where is the next generation of property academics coming from. Chance and opportunity are key elements in everyone's career; take advantage of the opportunities, but be selective; you do not have to say yes to everything.

Overall, we can look back at 30 years of property education in Australian universities and see that an excellent job has been done in preparing people for a diverse range of careers in the property industry.

Whilst approximately $50 \%$ of current PRRES members will retire over the next 5-10 years, this still leaves $50 \%$ actively involved in property education and property research. As a group of property educators, we have a responsibility to implement succession planning to ensure a seamless transition in helping develop the next generation of property academics. In particular, PRRES is to be commended for including younger property academics in a range of PRRES activities, including an active role on the PRRES board and strongly supporting the doctoral seminar program.

Are there future prospects for property academics? Yes, but it will require a refocusing around changing priorities; particularly driven by the RQF, as well as things being done differently by this new generation of property academics. I am sure they will do an excellent job and continue to develop property education and property research in the future. 


\section{REFERENCES}

Chin, W., Dent, P. and C. Roberts (2006), An exploratory analysis of barriers to investment and market maturity in South-East Asian cities. Journal of Real Estate Portfolio Management 12(1): 49-58.

Gallimore, P. and P. McAllister (2004), Expert judgement in the processes of commercial property market forecasting. Journal of Property Research 21(4): 337-360.

Lim, L.C, McGreal, W. and J. Webb (2006), Perception of real estate investment opportunities in Central/South America and Africa. Journal of Real Estate Portfolio Management 12(3): 261-276.

Ling, D. (2005), A random walk down Main Street: can experts predict returns on commercial real estate? Journal of Real Estate Research 27(2): 137-154.

RICS (2006), The future of surveying education. RICS, London. 